\title{
Jual Beli Bahan Bakar Premium Eceran
}

\author{
Yuliana \\ Sekolah Tinggi Agama Islam Hubbulwathan Duri \\ JL. Karya KM. 17 Desa Balaimkam Kabupaten Bengkalis, Riau \\ E-mail: Yulianashimeo9@gmail.com
}

\begin{abstract}
This research is motivated, because of the reduction in the quantity of retail premium perliter quantity. Phenomena based on field survey that there are some patterns of retail premium that become the background, namely retail premium sales pattern with the first pattern, retail premium sales with bottled patterns accompanied by prices, and retail premium sales with bottled patterns accompanied by a reduction in quantity. As for the formulation of the problem how to buy and sell retail premium fuel? This research aims to find out which muamalah is true or legitimate, in accordance with Islamic law based on the quran hadits, for the general public towards buying and selling retail premium fuel. This research is a qualitative research that is collecting data source from the subject under study. After conducting field research and getting conclusions using the qiyas method to explore syara' law from what is concluded from the field.
\end{abstract}

Keywords: buy and sell, fuel, premium.

\begin{abstract}
Abstrak
Penelitian ini dilatarbelakangi, karena adanya pengurangan takaran kuantitas perliter premium eceran. Fenomena yang berdasarkan surve di lapangan bahwa ada beberapa pola premium eceran yang menjadi latar belakang yaitu pola penjualan premium eceran dengan pola pertamini, penjualan premium eceran dengan pola botolan disertai harga, dan penjualan premium eceran dengan pola botolan disertai pengurangan kuantitas. Adapun rumusan masalah bagaimana Jual Beli Bahan Bakar Premium Eceran? Penelitian ini bertujuan untuk mengetahui bermuamalah yang benar atau salah, sudah sesuai dengan syariat Islam berlandaskan al-Quran dan Hadis, bagi masyarakat umum terhadap jual beli bahan bakar minyak premium eceran. Penelitian ini merupakan penelitian kualitatif (field reseach) yaitu mengumpulkan data yang bersumber dari subjek yang diteliti. Setelah melakukan penelitian lapangan dan mendapatkan kesimpulan mengunakan metode qiyas untuk menggali hukum syara' dari apa yang simpulkan dari lapangan.
\end{abstract}

Kata Kunci: Jual Beli, Bahan Bakar, Eceran. 


\section{Jual Beli Bahan Bakar Premium Eceran}

Yuliana

\section{Pendahuluan}

Ajaran Islam mengatur berbagai aspek kehidupan secara menyeluruh mulai dari hal yang sekecil-kecilnya sampai pada hidup bermasyarakat luas, semua itu ada aturan dan ketentuan. Salah satu segi kehidupan manusia itu hidup adalah berusaha, berdagang dan lain-lain. Untuk mencapai kemajuan dan tujuan hidup manusia diperlukan kerja sama sebagaimana dijelaskan dalam firman Allah surah al-Maidah ayat 2. Ayat tersebut menyuruh untuk tolongmenolong dalam (mengerjakan) kebajikan dan ketakwaan.

Di antara sekian banyak aspek kerja sama yang mengatur hubungan sesama manusia, ekonomi perdagangan termasuk salah satu diantaranya bahkan aspek ini sangat penting peranannya dalam meningkatkan kesejahteraan hidup manusia. Setiap orang akan mengalami kesulitan dalam memenuhi hajat hidupnya jika tidak bekerja sama dengan orang lain. Salah satu hal yang paling mendasar dalam pemenuhan kehidupan manusia adalah interaksi sosial dengan manusia lain dalam memenuhi kebutuhan hidupnya yang disebut dengan mu'amalat. Nasrun Haroen mengemukakan bahwa yang dimaksud dengan mu'amalat adalah suatu aktifitas yang dilakukan oleh seseorang dengan seseorang atau beberapa orang dalam memenuhi kebutuhan masing-masing.

Persoalan muamalah merupakan suatu hal yang pokok dan menjadi tujuan penting agama Islam dalam upaya memperbaiki kehidupan manusia. Atas dasar itu, syariat muamalah diturunkan Allah hanya dalam bentuk yang global dan umum saja, dengan mengemukakan berbagai prinsip dan norma yang dapat menjamin prinsip keadilan dalam bermuamalah antara sesama manusia. Dalam satu riwayat, Rasulullah pernah ditanya tentang usaha yang baik, saat itu beliau menjelaskan dua bentuk usaha yaitu usaha seseorang dengan tangannya sendiri dan jual beli.

Jual beli yang baik dalam hadis di atas adalah jual beli yang tidak disertai dengan tipuan dan khianat dan dapat diterima (sah) menurut hukum syara' serta diberi pahala pihak penjual dan pembelinya. Untuk menentukan apakah jual beli tersebut sah atau tidak menurut syara' tergantung pada dipenuhinya rukun dan syarat. Selain itu, asal pokok di dalam jual beli harus didasari suka sama suka antara penjual dan pembeli. Hal itu harus terpenuhi dalam arti jual beli yang tidak mengandung unsur paksaaan serta dapat merugikan pihak lain. Apabila jual beli itu mengandung unsur paksaan serta dapat merugikan pihak lain, maka 
itu termasuk jual beli yang bathil atau tidak sah. Salah satu yang menjadi kriteria suatu transaksi yang hak dan sah adalah adanya unsur suka sama suka di dalamnya. Segala bentuk transaksi yang tidak terdapat unsur suka sama suka, maka transaksi itu adalah bathil, yang berarti memakan harta orang lain secara tidak sah.

Hukum jual beli ini bermacam-macam bentuknya tergantung dari pelaksanaan dan tujuannya. Pada dasarnya jual beli itu boleh tetapi bisa jadi wajib bila dilakukan dengan orang yang membutuhkan, namun bisa jadi haram kalau tidak sesuai dengan ajaran Islam seperti jual beli yang mengandung unsur penipuan, riba dan sebagainya. Hal-hal yang dijelaskan di atas adalah konsep jual beli dalam fiqh muamalah. Berhubungan dengan persoalan jual beli, di sini penulis mendapatkan sebuah permasalahan dalam hal jual beli bahan bakar minyak premium eceran. Dimana jual beli yang dilakukan oleh penjual disini berbeda dengan jual beli premium eceran pada biasanya. Terhadap kasus jual beli premium eceran, mengemukakan tentang cara penjualan bahan bakar minyak premium eceran.

Ada dua cara yang dilakukan pedagang eceran untuk menjalankan usahanya. Pertama, pola penjualan yang dilakukan dengan cara pertamini. Pola eceran pertamini merupakan ide bisnis kreatif, yang menggunakan literan yang lebih modern. Pertamini merupakan tempat berjualan bahan bakar yang dikelola secara perorangan tanpa badan hukum. Pertamini suatu alat yang dibuat menyerupai SPBU milik pertamina namun dengan skala kecil. Meskipun disebut pertamini, namun alat ini bukan alat resmi yang dikeluarkan oleh pertamina. Selain memakai pompa atau literan manual dengan gelas takaran berkapasitas lima liter, pertamini juga dilengkapi dengan batas tera pada setiap satu liternya. Tangki cadangan merekapun memakai drum 200 liter yang ditanam atau dimasukkan di bawah bangunan khusus berdinding beton. Bensin yang dibeli dari SPBU kemudian dimasukkan ke dalam drum sebelum dijual kepada konsumen. Kedua, pola premium eceran menggunakan bermacam wadah seperti: botol aqua, botol beling dan derijen. Penjualan premium eceran pola botolan yang tidak mengunakan alat takaran dalam mengisi botol hanya perkiraan yang dibantu dengan alat selang untuk memasukkan premium ke dalam botol. Dari hasil wawancara, penulis mengetahui bahwa jual beli premium 


\section{Jual Beli Bahan Bakar Premium Eceran}

Yuliana

eceran yang dilakukan penjualan dengan model perbotol dimana penjual memasang papan harga tanpa menulis keterangan satu liter.

Untuk lebih jelasnya, proses terjadinya jual beli ini perorangan yang mengundang ketertarikan masyarakat lain dan jual beli ini mulai dikenal ditengah-tengah masyarakat. Penelitian awal dilakukan dalam bentuk wawancara dengan beberapa orang pedagang untuk mengetahui proses mereka mendapatkan bahan bakar minyak yaitu penjual premium eceran setiap harinya membeli di SPBU (Stasiun Pengisian Bahan Bakar Umum) pada siang dan malam hari.

Pedagang premium eceran sering membeli ke SPBU pada malam hari karena mudah untk mendapatkan premium tersebut, pada jam 03.03-05.00 WIB dengan pembeli memberikan uang tips ke petugas SPBU Rp.5000,00 per-derijen yang berisi 34 liter per-derijen harganya Rp. 221.00o,oo. Kemudian dijual kembali dalam bentuk eceran, mereka menjual premium eceran dengan mengambil keuntungan dari harga di SPBU Rp.6.500 kemudian dijual dengan harga Rp.7000,00. Untung diperoleh dari satu liter Rp.500 jika penjual menjual 34 liter maka untungnya Rp. 17.000 dari 34 liter. Setelah itu penjual eceran mengambil keuntungan dari 34 liter menjadi 35 liter. Keuntungan yang diperoleh dari 35 liter yaitu Rp. 18.000,oo. Kentungan per-hari jika penjualan 100 liter yaitu Rp. 60.000,00. Sedangkan pada satu bulan keuntungan diperoleh Rp.1.800.000,oo jika satu tahun Rp.21.600.000,oo. Penjualan premium eceran 100 liter perhari.

Berdasarkan hasil wawancara dengan beberapa penjual bahan bakar minyak premium eceran yaitu Bapak Syafdal, Bapak Adnal dan Bapak Arif, Ibuk Ningsih, Ibuk Diana, dan Bapak Usman. Mereka mengatakan menjual bahan bakar minyak pemium eceran adalah salah satu mata pencarian bagi mereka. Karena pekerjaan tersebut menambah hasil perhari dari mengambil untung dengan cara penjualan bahan bakar minyak premium eceran perbotolnya.

Dalam transaksi jual beli premium eceran yang dilakukan oleh pertamini bersifat moderen itu tidak ada masalah karena alat yang digunakan yaitu tabung transparan, mempunyai garis perliter dan harga yang ditetapkan perliternya. Sedangkan pada eceran perbotol dilakukan dengan penjualan premium eceran dengan harga perbotol, dan penjualan premium eceran dengan perliter disertai penetapan harga. Jika penjualan dengan harga perbotol tidak ada masalahnya 
tetapi jika penjualan perliter disertai penetapan harga disinilah timbul suatu masalah dimana, penjual mengurangi kuantitas premium eceran sehingga perliter tidak cukup. Disinilah peluang bagi penjual untuk melakukan suatu perbuatan penipuan untuk mendapatkan keuntungan bagi pedagang yang tidak jujur.

Jika dikaitkan dengan realita praktek jual beli yang menimbulkan pertanyaan bagi peneliti apakah pelaksanaan jual beli premium eceran ini sesuai dan dibenarkan oleh Islam atau tidak. Sedangkan yang dominan menggunakan pertamini untuk menjual premium eceran yang mempunyai sifat transparan dalam praktek jual beli premium eceran sesuai dengan syariat.

\section{TINJAUAN TEORITIK}

Jual beli dibolehkan dan telah dipraktekkan sejak masa Rasulullah sampai sekarang. Jual beli disyari'atkan oleh Allah SWT kepada hamba-Nya sebagai keluasaan bagi mereka dalam memenuhi kebutuhan hidupnya. Setiap manusia mempunyai kebutuhan akan sandang, pangan, dan lainnya. Kebutuhan tersebut tak pernah terhenti dan senantiasa diperlukan selama manusia itu hidup. Tidak seorangpun bisa memenuhi kebutuhan hidupnya sendiri oleh karenanya ia dituntut untuk berhubungan sesamanya. Dalam hubungan jual beli, semuanya memerlukan pertukaran, seseorang memberikan apa yang dimilikinya untuk memperoleh sesuatu sebagai pengganti sesuai kebutuhannya.

Seorang yang bermaksud melakukan jual beli, berkewajiban mengetahui hal-hal yang dapat mengakibatkan jual beli itu sah atau tidak (fasid). Ini dimaksudkan agar muamalah berjalan sah dan segala sikap dan tindakannya jauh dari kerusakan yang tidak dibenarkan. Jual beli sebagai sarana tolong-menolong antara sesama manusia mempunyai landasan yang amat kuat dalam Islam. Bagi yang bergerak dibidang perdagangan, maka harus mengetahui hukum dari jual beli tersebut. Hukum itu berkaitan dengan sah dan rusaknya jual beli yang akan dilakukan. Hal ini bertujuan agar jual beli yang dilakukan sah secara hukum dan terhindar dari hal-hal yang tidak dibenarkan. Setiap orang harus memperhatikan hukum jual beli apabila ingin mendapat rezki yang halal. Tentang penghasilan yang halal, Ali r.a berkata Rasulullah saw bersabda.

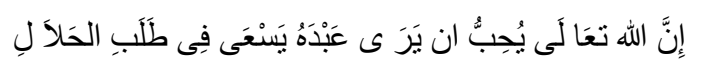




\section{Jual Beli Bahan Bakar Premium Eceran}

Yuliana

Artinya: Sesungguhnya Allah swt, senang melihat hamba-Nya berusaha mencari rezeki yang halal (HR. Thabrani dan Dailami)

Anas bin Malik r.a Meriwayatkan bahwa Rasulullah saw bersabda.

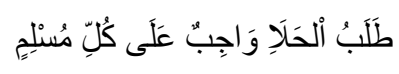

Artinya: Mencari harta yang halal wajib bagi setiap Muslim.

Mengenai anjuran bergegas untuk mengais rezeki, Tirmidzi meriwayatkan dari dalam al-Qur'an yang menjelaskan tentang kebolehan melakukan jual beli adalah surat al-Baqarah ayat 275 yang berbunyi sebagai berikut:

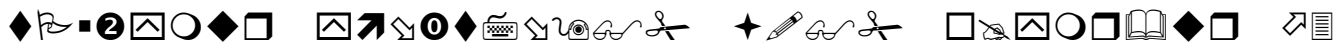

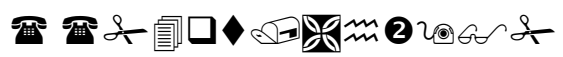

Artinya: Padahal Allah telah menghalalkan jual beli dan mengharamkan riba.

(Q.S al-Baqarah: 275).

Dalam ayat ini terkandung anjuran untuk tidak memakan harta sebagian yang lain dengan cara yang haram, diantaranya riba, judi, dan semua perkara yang telah Allah haramkan. Jual beli harus didasarkan pada asas suka sama suka antara dua orang yang melakukan transaksi jual beli, sebelum keduanya berpisah dan meninggalkan tempat transaksi, atas dasar suka sama suka dari keduanya atas akad yang disepakati antara keduanya. Makna dari ungkapan suka sama suka di sini dapat dinyatakan sebagai perwujudan dari sikap kedua pelaku perdagangan yang menyetujui segala hal-hal yang berlaku dalam perniagaan tersebut, sehingga tidak ada pihak yang akan dirugikan jika perniagaan telah dilangsungkan. Dalam surat Al-Baqarah (2): 198 yang berbunyi sebagai berikut:

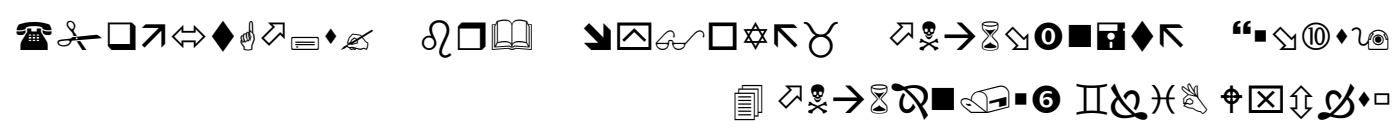

Artinya: Tidak ada dosa bagimu untuk mencari karunia (rezki hasil perniagaan) dari Tuhanmu (Q.S al-Baqarah:198)

Ayat di atas menjelasakan tentang kebolehan melakukan jual beli di mana jual beli tersebut berlangsung dengan cara suka sama suka antara penjual dan pembeli tanpa ada unsur paksaan. Allah menyuruh manusia untuk mencari rezeki di muka bumi ini. Salah satunya adalah dengan hasil perniagaan. Menurut Al-Hadis, jual beli dalam Sunnah Rasulullah SAW di antaranya hadis dari Rifa'ah Ibn Rafi' bahwa: 


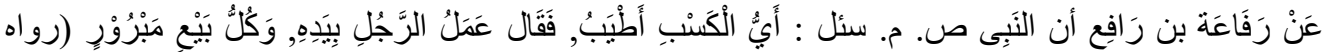

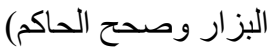

Artinya : Dari Rafi'ah ibn Rafi' bahwasanya Nabi SAW pernah ditanya orang : apa mata pencaharian yang paling baik ? Nabi SAW menjawab : "Seseorang yang bekerja dengan tangannya sendiri dan tiap-tiap jual beli yang halal”. (Diriwayatkan oleh al-Bazar dan ditashihkan oleh al-Hakim).

Hadis ini menjelaskan tentang jual beli yang jujur tanpa diiringi sebagai perbuatan yang paling baik yang akan mendapatkan berkah dari Allah SWT. Jual beli yang tidak disertai dengan tipuan dan khianat, dapat diterima (sah) menurut hukum syara' serta pahala pihak penjual dan pembelinya. Dalam Hadis dari Abi Sa’id al-Khudri yang diriwayatkan oleh al-Baihaqi, ibn Majah dan ibn Hibban, Rasulullah saw menyatakan:

$$
\text { إِنَّمَا الَيَيْعُ عَنْ تَزَ اضٍ }
$$

Artinya: Jual beli didasarkan kepada suka sama suka.

Dalam riwayat at-Tirmizi Rasullah bersabda:

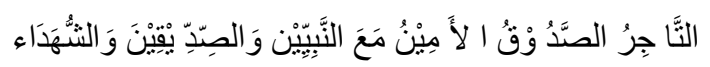

Artinya: Pedagang yang jujur dan terpercaya itu sejajar (tempatnya disurga) dengan para nabi, para saddiqin, dan para syuhada.

Juga terdapat dalam Surat an-Nisa ayat 29 yang berbunyi:

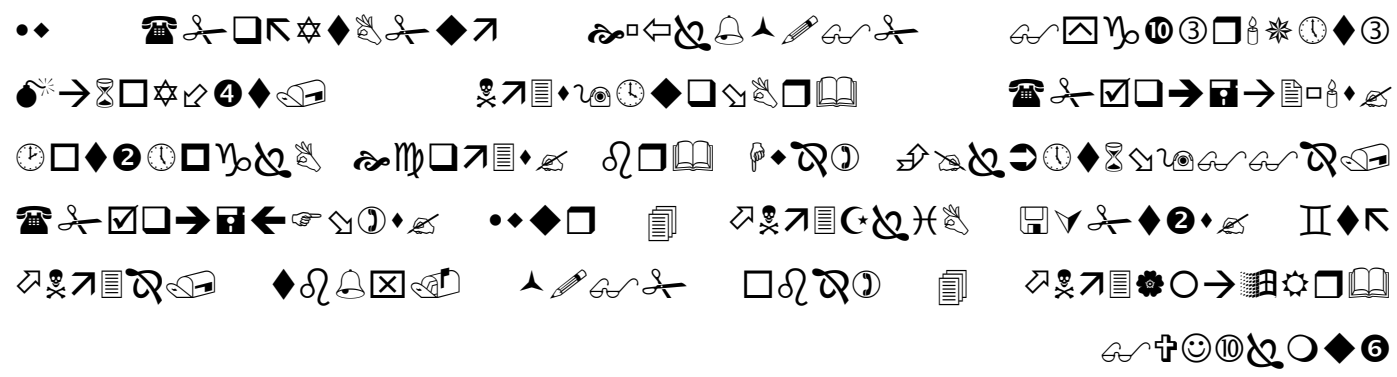

Artinya: Hai orang-orang yang beriman, janganlah kamu saling memakan harta sesamamu dengan jalan yang batil, kecuali dengan jalan perniagaan yang Berlaku dengan suka sama-suka di antara kamu. dan janganlah kamu membunuh dirimu (Q.S an-Nisa: 29) 


\section{Jual Beli Bahan Bakar Premium Eceran}

Yuliana

Dalam surat an-Nisa' ini, Allah menjelaskan bahwa dilarang untuk mengambil harta orang lain dengan cara yang bathil, namun boleh mendapatkannya dengan jalan perniagaan. Perniagaan di sini yaitu dengan melakukan jual beli yang berlaku atas dasar suka sama suka diantara kedua pihak yang melakukan perniagaan tersebut. sebagaiamana hadis Nabi sebagai berikut:

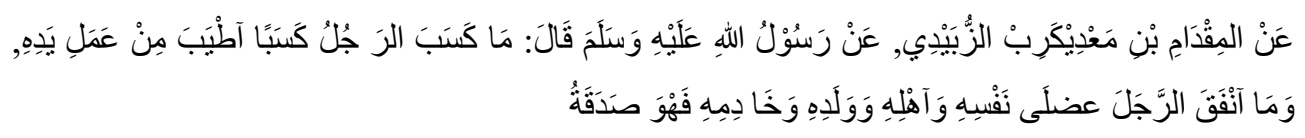

Artinya: Dari Miqdam bin Ma'dikarib Az-zubaidi, dari Rasulullah SAW bersabda,"Tidaklah seseorang mendapatkan sesuatu yang lebih baik dari pada yang ia dapat dari usahanya sendiri. Dan apa yang dinafkahi oleh seseorang untuk dirinya, keluarganya, anaknya, dan pelayanya adalah bernilai sedekah.

Ayat dan hadis di atas menggambarkan bagaimana perhatian agama Islam terhadap masalah jual beli. Agama Islam juga memberikan petunjuk pelaksanaan jual beli tersebut, melakukan jual beli agar tidak bercampur antara yang halal dan haram, yang hak dan bathil. Untuk itu Islam memberikan peraturan-peraturan yang mengikat dan membatasi manusia dalam bermuamalah, supaya dalam memenuhi kebutuhannya tidak menempuh cara yang dimurkai Allh SWT dan tidak pula merugikan orang lain.

\section{METODE PENELITIAN}

Penelitian ini merupakan penelitian lapangan (field research), yang berusaha mengumpulkan data yang bersumber dari subjek yang diteliti. Penelitian ini pada hakekatnya merupakan metode yang menentukan secara khusus dari realita yang terjadi di tengah masyarakat. jenis data yang digunakan berupa data primer. Dengan metode observasi, wawancara, dan dokumentasi. Observasi yang dilakukan kepada pedagang premium eceran bagaimana mereka melakukan praktek jual beli premium eceran. Sedangkan wawancara dilakukan sebagai upaya penggalian data dari nara sumber untuk mendapatkan informasi atau data secara langsung lebih akurat dari orang-orang yang berkaitan khususnya para penjual premium eceran.

Analisis yang dilakukan merupakan kualitatif yaitu upaya yang dilakukan dengan jalan memeriksa, mengklasifikasikan, menginterpretasikan, menganalisa dan menarik kesimpulan dari data tersebut. Kesimpulan diambil dengan 
mengunakan metode deskriptif kualitatif, yaitu memaparkan data tanpa mengunakan hitungan, melainkan hanya berupa penalaran analisis dan tanggapan terhadap fakta yang terjadi.

Setelah melakukan penelitian lapangan dan mendapatkan kesimpulan peneliti mengunakan metode qiyas untuk menggali hukum syara' dari apa yang penulis simpulkan dari lapangan. Qiyas adalah menghubungkan (menyamakan hukum) sesuatu yang tidak ada ketentuan hukumnya dengan sesuatu yang ada ketentuan hukumnya karena ada persamaan 'illat. Mengunakan qiyas dalam istinbath hukum penelitian penulis karena dengan hukum yang telah ada dalam nash akan menyamakan hukum yang belum ada yang penulis teliti.

\section{HASIL DAN PEMBAHASAN}

\section{Fenomena Penjualan Premium Eceran}

Perkembangan ekonomi berjalan seiring dengan berkembangnya kehidupan manusia sebagai pelaku ekonomi. Hal ini mendesak manusia untuk terus berusaha, bekerja, dan berpikir agar kebutuhan kehidupan terpenuhi. Di samping itu, manusia juga dituntut untuk terus meningkatkan kedekatannya dengan Maha Pencipta dari waktu ke waktu. Manusia adalah makhluk sosial yang membutuhkan bantuan orang lain untuk memenuhi kebutuhan hidupnya.

Muamalah merupakan suatu proses atau usaha yang dilakukan oleh manusia dalam rangka memenuhi hajat hidup sekaligus sebagai sarana beribadah kepada Allah SWT. Salah satu bentuk muamalah yang dilakukan adalah jual beli yang merupakan salah satu bentuk pencarian. Berbagai macam bentuk perdagangan yang terjadi di tengah-tengah masyarakat, di antaranya adalah jual beli barang-barang yang tidak bisa dihitung satu persatu sehingga membutuhkan alat untuk bisa menghitungnya dengan mudah seperti timbangan, takaran dan sebagainya.

Timbangan yang artinya banding. Di samping itu, kata timbang juga dimaknai dengan timbang atau sama berat. Dalam kamus besar bahasa Indonesia, timbangan berarti tidak berat sebelah, sama berat. Kata timbang bila diakhiri oleh imbuhan-an dapat dipahami sebagai alat yang digunakan untuk menimbang yaitu alat untuk menentukan apakah suatu benda sudah sama berat dengan benda yang dijadikan ukur (standar) atau belum. 


\section{Jual Beli Bahan Bakar Premium Eceran}

Yuliana

Berdasarkan penjelasan di atas, kata timbang ini mencerminkan keadilan, karena berat (banding) adalah salah satu dari unsur keadilan. Apabila sama berat dalam timbangan menyangkut hak manusia. Dalam timbangan terdapat beberapa unsur. Pertama: alat yang digunakan untuk menimbang. Kedua: benda yang akan ditimbang. Ketiga: benda yang dijadikan sebagai alat ukur standarnya. Yang timbang dalam hal ini adalah massa atau berat bendanya.

Kata menimbang sangat berbeda dengan menakar. Secara umum kedua kata ini dibedakan pada objek yang timbang atau yang ditakar. Kata menimbang lebih menitikberatkan pada massa benda atau berat benda yang akan ditimbang. Sedangkan kata menakar justru lebih menitikberatkan pada kuantitas barang yang ditakar, maka UU membedakan antara alat takar dengan alat timbang, sebagai berikut: (1) Alat ukur adalah alat yang diperuntukan atau dipakai bagi pengukuran kuantitas atau penakaran. (2) Alat timbang adalah alat yang diperuntukan atau dipakai bagi pengukur massa atau penakaran.

Dasar hukum timbangan, Penimbangan dalam dunia Islam sangan terkait dengan kegiatan ekonomi. Terutama dalam hal ini adalah kegiatan jual beli. Islam memberikan tuntutan yang terkait degan seluruh aspek kehidupan. Termasuk salah satunya adalah aspek pemenuhan kehidupan berupa praktik jual beli. Dalam jual beli, Islam memerintahkan para pedagang untuk melaksanakan jual beli yang bersih.

Segala transaksi yang dilakukan harus berlandaskan pada hukum Islam. Memenuhi takaran adalah salah satu bentuk keadilan dalam bermuamalah. jika takaran yang digunakan tidak sesuai dengan nominal pembelian maka akan ada pihak yang akan dirugikan dan tentunya akan menimbulkan mudharat didalamnya. Pada pembahasan ini, penulis arahkan kepada jual beli premium eceran yang mengunakan alat ukur takaran.

Ada beberapa pola penjualan premium eceran sebagai berikut:

(a) Penjualan Premium Eceran dengan Pola Pertamini. Praktek jual beli dengan alat-alat yang digunakan dalam prosesnya mengalami perkembangan seiring dengan pencapaian manusia dibidang teknologi. Model eceran pertamini merupakan ide bisnis kreatif, yang menggunakan literan yang lebih modern. Pertamini merupakan tempat berjualan bahan bakar yang dikelola secara perorangan tanpa badan hukum. Pertamini suatu alat yang dibuat menyerupai SPBU milik pertamina namun dengan skala kecil. Meskipun 
disebut pertamini, namun alat ini bukan alat resmi yang dikeluarkan oleh pertamina. Selain memakai pompa atau literan manual dengan gelas takaran berkapasitas lima liter, pertamini juga dilengkapi dengan batas tera pada setiap satu liternya. Tangki cadangan merekapun memakai drum 200 liter yang ditanam atau dimasukkan di bawah bangunan khusus berdinding beton. Bensin yang dibeli dari SPBU kemudian dimasukkan ke dalam drum sebelum dijual kepada konsumen.

Daliyusman (53 tahun) penjual premium eceran dengan mengunakan alat pertamini mengatakan bahwa untuk mendirikan sebuah pertamini membutuhkan dana Rp.3.00o.ooo,oo dari bahan untuk mendirikan pondok pertamini serta alat-alat lainnya seperti tabung, selang yang pada saat awal pembelian alat tersebut dipesan ditempat temannya yang tinggal di Payakumbuh. Mengunakan alat pertamini untuk menjual premium eceran mendapatkan kepercayaan dari pembeli dari alat yang transparan. Takaran perliter dapat dilihat secara langsung dengan harga yang tidak jauh beda dari harga SPBU seperti harga sekarang Rp.7.300,00-perliter di SPBU, kemudian saya jual premium eceran dengan pola pertamina Rp.8.500,00perliter karena motivasi saya berjualan dengan jujur serta mendapatkan keuntungan yang diberkahi dijalan Allah berdasarkan syari'at.

Rinawati (50 tahun) mengatakan bahwa dalam penjualan menggunakan alat pertamini keuntungan yang diperoleh perhari banyak serta dengan penjualan seperti ini membantu pembeli dalam memperoleh premium dengan mudah yang sesuai dengan takaran perliternya. Niat saya berjualan premium eceran agar memperoleh ridhoan Allah dalam pekerjaan yang dilakukan.

Hal yang serupa juga dilontarkan oleh Rihanda (50 tahun) bahwa mengatakan dalam sistem praktek penjualan premium eceran tidak hanya saja mencari keuntungan semata tetapi mencari ke ridhoan Allah dalam mencari nafkah yang halal sesuai dengan tuntunan syariat. Dimana antara penjual dan pembeli tidak ada rasa dirugikan dalam jual beli premium eceran dengan pola pertamini.

Daliyusman (53 tahun) mengatakan bahwa dimulainya perdagangan dengan mengunakan alat pertamini sejak tahun 2011, dimana bapak tersebut tertarik dari alat pertamini yang moderen tersebut yang transparan seperti 


\section{Jual Beli Bahan Bakar Premium Eceran}

Yuliana

alat di SPBU jadi memudahkan dalam menjual premium eceran dan dilihat dari pengalaman teman yang menggunakan alat itu memperoleh untung yang besar karena pembeli merasa aman dan praktis mendapatkan premium eceran. Tetapi sekarang tidak susah lagi untuk membeli tabung pertamini karena sudah ada yang tersedia di Pusat Pasar Raya Padang salah satu toko namanya Toko Aden pemiliknya orang cina. Untuk melakukan penjualan yang didasarkan kejujuran tidak semata mencari keuntungan melainkan juga beribadah kepada Allah SWT. Maka dengan adanya alat pertamini ini terbantu dalam penjualan premium eceran yang sesuai dengan takarannya

Penjualan dengan pertamini premium eceran yang terjual perharinya maksimal 6 derijen yang berisi 34 liter. Harga yang dijual oleh pedagang perliter tersebut Rp. 8.500,o0. Pedagang mengatakan dengan alat yang digunakan pertamini menarik pembeli karena sifat yang dimiliki transparan juga adil dalam takaran. Sehinga setiap harinya memperoleh keuntungan yang memuaskan. Meskipun transaksi jual beli mengalami perkembangan tentunya jual beli tersebut haruslah dilandasi oleh prinsip suka sama suka antara penjual dan pembeli.

Dalam transaksi jual beli premium eceran yang dilakukan dengan eceran pertamini yang bersifat moderen itu tidak ada masalah karena alat yang digunakan yaitu tabung transparan, mempunyai garis perliter dan harga yang ditetapkan perliter. Pertamini merupakan alat yang memudahkan dalam melaksanakan transaksi jual beli premium eceran serta keuntungan yang diperoleh perhari memuaskan.

b) Penjualan Premium Eceran dengan Pola Botolan Disertai Pengurangan Kuantitas. Penjualan premium eceran dalam model per botol yang tidak mengunakan alat takaran dalam mengisi botol hanya perkiraan yang dibantu dengan alat selang untuk memasukkan premium ke dalam botol, sebagian botol tidak bersifat trasparan dan juga tidak memiliki batas tera yang ada pada pertamini. Jual beli premium eceran yang dilakukan penjualan dengan model perbotol dimana penjual memasang papan harga tanpa menulis keterangan satu liter.

Safdal (50 tahun) mengatakan bahwa untuk mendapatkan bahan bakar minyak yaitu penjual premium eceran setiap harinya membeli di SPBU (Stasiun Pengisian Bahan Bakar Umum) pada siang dan malam hari tetapi 
yang sering dilakukan pada malam hari karena mudah untuk mendapatkan premium tersebut, pada jam 03.03-05.00 WIB dengan pembeli memberikan uang tips kepada SPBU Rp.5000,o0 per-derijennya yang berisi 34 liter perderijen harga Rp. 221.000,00.

Penjualan premium eceran dalam bentuk botolan, dengan mengambil untung dari harga di SPBU Rp.6.500 kemudian dijual dengan harga Rp.7000,00. Untung diperoleh dari satu liter Rp.500 jika penjual menjual 34 liter maka untungnya Rp. 17.00o dari 34 liter. Setelah itu penjualan eceran mengambil keuntungan dari 34 liter menjadi 35 liter. Keuntungan yang diperoleh dari 35 liter yaitu Rp. 18.00o,oo. Kentungan per-hari penjualan 100 liter yaitu Rp. 60.000,00. Sedangkan pada satu bulan keuntungan diperoleh Rp.1.800.000,oo jika satu tahun Rp.21.600.000,o0. Penjualannya 100 liter perhari bahkan lebih ketika stok di SPBU sudah habis. Hasil wawancara yang dilakukan penulis di atas pada tahun 2014 ketika harga premium stabil.

Arif (50 tahun) mengatakan penjualan premium eceran dengan mengurangi takaran namun tetap menjual dengan harga yang berlaku dipasaran, seperti pedagang premium eceran yang mengurangi takaran 1 liter/ $1000 \mathrm{ml}$ menjadi $800 \mathrm{ml}$ atau $900 \mathrm{ml}$, kemudian ia tetap menjualnya dengan harga 1 liter, seperti harga 1 liter premium eceran Rp.8000,oo,tetap di jual dengan harga Rp.80oo,oo- namun isinya dalam 1 liter itu Cuma $800 \mathrm{ml}$ atau $900 \mathrm{ml}$.

Adnal (51 tahun) bahwa dalam melakukan pengurangan takaran untuk memberikan harga murah kepada pembeli, pedagang yang mengurangi takaran premium eceran 1 liter menjadi $800 \mathrm{ml}$ atau $900 \mathrm{ml}$, kemudian ia menjualnya dengan harga $800 \mathrm{ml}$ atau $900 \mathrm{ml}$, namun dia tetap mengatakan kepada pembeli bahwa premium eceran itu adalah 1 liter.

Hal yang serupa dilakukan oleh Ningsih (52 tahun), karena untuk memperoleh keuntungan dari praktek yang dilakukan dengan pengurangan takaran kuantitas perliter menjual premium eceran perharinya 100 liter perhari. Penjualan pada satu minggu Ibuk Ningsih menghabiskan premium eceran 600 liter dengan pola pengurangan kuantitas perliter premium eceran dari satu derijen yang isi 34 liter.

c. Penjualan Premium Eceran dengan Botolan Disertai Harga 
Diana (51 tahun) mengatakan bahawa dalam melakukan kegiatan penjualan premium eceran tidak melakukan pengurangan pada takaran namun menjual premium eceran dengan harga perbotol, botol yang digunakan hanya berisi satu liter saja. Seperti menjual premium eceran 1 liter namun dengan harga $1000 \mathrm{ml}$ yaitu Rp. 9.000,00 perbotol. Dalam pola yang digunakan perbotol pedagang membuat garis untuk menandai dalam setiap pengisiannya. Jika derijen yang berisi 35 liter tetap dijual dengan 35 liter. Keuntungan yang diperoleh oleh pedagang dari harganya saja tanpa pengurangan takaran premium eceran.

Pedagang premium eceran yang mengunakan botolan hanya disertai penetapan harga seperti pedagang yang menjual premium eceran 1 liter namun dengan harga $1000 \mathrm{ml}$ yaitu Rp.9.000,o0 perbotolnya. Dalam pola yang digunakan perbotolnya pedagang membuat garis untuk menandai dalam setiap pengisiannya. Jika derijen yang berisi 35 liter tetap dijual dengan 35 liter. Keuntungan yang diperoleh oleh pedagang dari harganya saja tanpa pengurangan takaran premium eceran.

Dari beberapa kasus di atas, dapat kita lihat bahwa ada pedagang yang mengurangi takaran untuk pemberian harga murah. Pada saat sekarang, banyak sekali kasus-kasus ini terjadi, pada umumnya dalam jual beli premium eceran. Dalam hal ini, pembeli tidak mengetahui bahwa sebenarnya barang yang dia beli itu takarannya tidak sama dengan takaran yang dikatakan oleh penjual.

\section{Persepsi Para Pedagang Mengenai Penjualan Premium Eceran}

Ajaran Islam mengatur berbagai aspek kehidupan secara menyeluruh mulai dari hal yang sekecil-kecilnya sampai pada hidup bermasyarakat luas, semua itu ada aturan dan ketentuan. Salah satu segi kehidupan manusia itu hidup adalah berusaha, berdagang dan lain-lain. Untuk mencapai kemajuan dan tujuan hidup manusia diperlukan kerja sama.

Adnal (51 tahun) mengatakan tujuan dari berdagang adalah keuntungan. Tidak bisa pungkiri, bahwasannya ada penjual yang jujur dalam berdagang dan ada yang tidak. Penjual yang jujur akan memberikan informasi kepada pembeli mengenai daganggannya. Sebaliknya, penjual yang tidak jujur tidak akan memberitahukan informasi kepada pembeli bagaimana politik ia dalam 
berdagang. Dalam hal pengurangan takaran, tidak ada pedagang yang mengatakan kepada pembeli bahwa yang dijual itu takarannya dikurangi. Karena jika demikian, maka pembeli akan berpikir bahwa membeli di tempat pedagan tersebut sama saja dengan membeli di tempat lain tidak ada untungnya.

Penjualan premium eceran yang saya lakukan dengan mengurangi takaran perliter untuk mendapat keuntungan dengan cara demikian merupakan suatu kebiasaan yang dilakukan meskipun mengetahui mengambil hak pembeli tetapi jika tidak dengan cara tersebut untung yang diperoleh sedikit, botol yang saya gunakan hanya botol merek aqua dan sms agar dalam pengisian memperoleh dari isi derijen berisi 34 liter menjadi 36 liter.

Saya tidak menggunakan botol yang berisi satu liter menghilangkan peluang saya mendapatkan liter yang saya jelaskan tadi. Jika saya menggunakan isi yang hanya satu liter kemudian saya bisa mengisi botolan tersebut dalam perkiraan mendapat keuntungan 1 liter saja dari derijen yang berisi 34 liter itu. Keuntungan yang diperoleh yaitu dari pengurangan takaran serta penetapan harga.

Penjual yang melakukan pengurangan takaran ini tetap menunjukkan kepada pembeli premium eceran yang dijualnya adalah sesuai atau sama takarannya dengan yang diminta oleh pembeli. Secara tidak langsung, tujuan mereka melakukan hal tersebut adalah untuk memperoleh keuntungan. Cara yang mereka lakukan adalah mencari keuntungan dengan merugikan pembeli karena pembeli tetap tidak mendapatkan apa yang dibelinya sesuai dengan apa yang dibayarkannya.

Penjualan premium eceran menggunakan botolan itu praktis tidak memerlukan mengeluarkan biaya yang banyak. Hanya modal bermacam botolan yang dibeli ditempat barang bekas di daerah pinggir Kota Padang bahkan bisa dipesan kepada seseorang yang bekerja mencari barang bekas. Dengan menjual dengan botolan mendapat keuntungan yang sesuai dengan modal. Pengurangan takaran premium eceran di Sarang Gagak sudah kebiasaan dilakukan oleh pedagang. Setiap premium eceran yang dijual oleh penjual kepada pembeli hanya ditakar dengan perkiraan mengunakan botolan.

Dari peryataaan di atas dapat pahami bahwa pengurangan takaran serta penetapan harga dalam jual beli premium eceran di Sarang Gagak dilakukan, karena penjual mengatakan premium eceran tersebut di dapat oleh penjual 


\section{Jual Beli Bahan Bakar Premium Eceran}

Yuliana

dengan susah payah bangun pada malam hari untuk mendapatkan premium di SPBU. Sehingga menjualnya kembali ke masyarakat penjual dengan cara tersebut menurutnya tidak ada masalah bagi pembeli

\section{Persepsi Pembeli Terhadap Penjualan Premium Eceran}

Penjualan yang dilakukan pedagang dengan mengunakan botolan tersebut cara yang dilakukan pedagang untuk memperoleh keuntungan dengan praktek bermuamalah, ada dengan cara penetapan harga serta ada pula pengurangan takaran cara seperti itulah yang mereka lakukan. Penjualan premium eceran yang dilakukan pedagang membantu pembeli untuk mendapatkan premium tanpa antri di SPBU. Tetapi dari kebiasaan mereka yang menjual mengunakan botolan tidak dipungkiri adanya pengurangan setiap perliternya, padahal seharusnya mereka sebagai pedagang harus memenuhi takaran.

Dari hasil wawancara yang dilakukan penulis, bahwa 66 mahasiswa sering membeli premiun eceran yang mengunakan alat perbotol. Sedangkan 54 orang tidak membeli premium eceran perbotol, mereka membeli di SPBU dan pertamini karena mengetahui akan pengurangan takarannya. Terhadap jual beli premium eceran adanya unsur pengurangan takaran dari 67 mahasiswa, Risa Bellwati mengetahui pengurangan takaran tetapi tetap membelinya dengan alasan mereka mengatakan kebiasaan penjual yang tidak jujur dalam melakukan takaran demikian juga halnya dengan 53 mahasiswa tidak menngetahui pengurangan takaran karena hanya beberapa kali membeli premium eceran di pinggir jalan.

Penjualan premium eceran yang dilakukan pedagang itu membantu bagi pengandara untuk lebih mudah mendapatkan bahan bakar minyak, dari antri panjang di SPBU. Tetapi dengan keterbutuhan pembeli tersebut mereka mengunakan cara untuk memperoleh keuntungan yang sebanyak-banyaknya. Dengan praktek penetapan harga perbotol tanpa ada kejelasan kuantitas takarannya, padahal pembeli membutuhkan sesuai dengan takaran yang pas untuk jarak yang akan ditempuhnya.

Pedagang yang melakukan praktek jual beli premium eceran, tentang akad yang lapaskan pembeli mengatakan "Apak saya membeli satu liter premium" Apak pedagang mengatakan "ya” padahal pedagang tersebut kuantitas barang 
yang diperjualkan tidak dengan isi perliter tetapi perharga. Apak tersebut tidak menjelaskan kepada pembeli. Tetap saja menjualnya kepada pembeli.

Transaksi jual beli premium eceran yang mengunakan botolan, tentunya berlandasankan prinsip bermuamalah suka sama suka antara penjual dan pembeli. Dengan memberi hak antara penjual dan pembeli.

\section{KESIMPULAN}

Berdasarkan hasil penelitian, maka; (a) diharapkan kepada seluruh pedagang untuk dapat kiranya benar-benar mengetahui bagaimana tekhnis pelaksanaan jual beli yang sesuai dengan hukum Islam. (b) Diharapkan kepada pemerintah daerah untuk dapat memberikan penyuluhanan kepada para pelaku ekonomi umumnya dan pedagang premium eceran khususnya supaya lebih baik dalam menjalankan roda perekonomiannya. (c) Diharapkan kepada alim ulama, cerdik pandai maupun kepada instansi yang berwenang untuk dapat kiranya memberikan penerangan atau penyuluhan hukum dalam bidang muamalah agar tidak terjadi penyimpangan dalam praktek jual beli yang dilakukan oleh para pedagang premium eceran khususnya. (d) Diharapkan kepada pedagang premium eceran dengan berkembangannya teknologi pada zaman sekarang agar mengunakan alat pertamini sebagai tempat untuk melakukan jual beli premium eceran yang memudahkan dalam penjualan serta sifatnya yang transparan.

\section{DAFTAR PUSTAKA}

Azwar Saifuddin, Metode Penelitian, Yogyakarta: Pustaka Pelajar, 2001.

Bambang Prasetyo dkk, Metode Penelitian Kuantitatif, Jakarta: Rajawali Pers, 2014.

Bugin Burhan,Metodologi Penelitian Kualitatif, Jakarta: Raja Grafindo Persada, 2007.

Chaudry Sharif,Sistem Ekonomi Islam: Prinsip Dasar (Fundamental of Islamic Economic System), Jakarta: Kencana, 2016.

Denzin Norman K dan Lincoln Yvonna S, Hand Book Qualitative Research,Yogyakarta: Pustaka Pelajar, 2009.

Djam'an Satori dan Aan Komariah, Metodologi Penelitian Kualitatif, Bandung: Alfabeta, 2010.

Edwin Nasution Mustafa,Pengenalan Eksklusif: Ekonomi Silam, Jakarta: Kencana, 2007. 


\section{Jual Beli Bahan Bakar Premium Eceran}

Yuliana

Faizal Noor Henry,Ekonomi Manajerial, Jakarta: Raja Grafindo Persada, 2007.

GunawanHerry, Pengantar Transportasi dan Logistik, Jakarta:Raja Wali Pers,2015.

Ika Yunia Fauzia dan Abdul Kadir Riyadi, Prinsip Ekonomi Islam Perspektif Maqasid Al-Syariah, Jakarta: Kencana, 2014.

J.Setiadi Nugroho, Perilaku Konsumen: Perspektif Kontemporer pada Motif, Tujuan, dan Keinginan Konsumen, Jakarta: Kencana, 2003.

Jusmaliani, Bisnis Berbasis Syariah,Jakarta: Bumi Aksara, 2008.

KotherPhilip, Manajemen Pemasaran, Jakarta:Erlangga, 2006.

M. Nur Rianto Al Arif dan Euis Amalia, Teori Mikroekonomi Suatu Perbandingan Ekonomi Islam dan Ekonomi Konvensional, Jakarta: Kencana, 2010.

Niti Susastro Mulyad,Perilaku Konsumen dalam Perspektif Kewirausahaan, Bandung: Alfabeta, 2012.

Nuruddin Iqbal Amiur, Ekonomi Syariah Menepis Badai Krisis dalam Semangat Kerakyatan,Bandung: Perdana Mulya Sarana, 2009

Oni Sahroni dan Adiwarman A.Karim, Maqasdid Bisnis \& Keunangan Islam Sistesis Fikih dan Ekonomi, Jakarta: Raja Grafindo, 2016.

Philip Kotler dan Gary Amstrong, Prinsip-Prinsip Pemasaran, Jakarta: Erlangga, 2001.

Pusat Pengkajian dan Pengembangan Ekonomi Islam (P3EI), Ekonomi Islam, Jakarta: Rajagrafindo Persada, 2014.

QardhawiYusuf, Norma dan Etika Ekonomi Islam, Jakarta: Gema Insani Press, 1997.

Rozalinda, Ekonomi Islam Teori dan Aplikasinya pada Aktivitas Ekonomi, Jakarta: Rajagrafindo Persada 2014.

SudarsonoHeri, Konsep Ekonomi Islam Suatu Pengatar, Yogyakarta: Ekonisia, 2004 .

Sudarsono Heri, Konsep Ekonomi Islam, Yogyakarta: Adipura, 2003.

Sugiyono, Memahami Penelitian Kualitatif, Bandung: Alfabeta, 2009.

SumarwanUjang, Perilaku Konsumen Teori dan Terapannya dalam Pemasaran, Bogor Selatan: Ghalia Indonesia, 2002. 